\title{
IS THE PRESENT ORGANIZATIONAL CULTURE OF HUNGARIAN COMPANIES AFFECTED BY THEIR PAST STATE OWNERSHIP?
}

\section{Ákos Jarjabka}

Associate Professor and Vice Dean of Academic and General Affairs, Faculty of Business and Economics, University of Pécs, 7622 Pécs Rákóczi út 80., Hungary

akos@ktk.pte.hu

\section{ABSTRACT}

This study examines empirically how culturally rooted behavior forms can be detected in Hungarian organizations that were state-owned before the transition. A hypothesis is established and tested through the statistical analysis of a questionnaire-based survey conducted at the Faculty of Business and Economics, University of Pécs, Hungary. The original hypothesis is confirmed by the results of the analysis.

\section{Indexing terms/Keywords}

Organizational culture; organizational culture change; cultural research; transition; former stateownership of companies

\section{Academic Discipline And Sub-Disciplines}

Management Studies

\section{SUBJECT CLASSIFICATION}

Organizational Culture Change

\section{TYPE (METHOD/APPROACH)}

Research paper, Survey

\section{Council for Innovative Research}

Peer Review Research Publishing System

Journal: Journal of Social Sciences Research

Vol. 6, No. 1

Jssreditor.cir@gmail.com

www.jssronline.com 


\section{INTRODUCTION}

Cultural research, as a subdiscipline of social sciences, aims at understanding present social and economic structures by analyzing the past. Cultural research appeared in the horizon of economic research only in the middle of the 20th century, for example in the works of Kluckhohn(1951), Mcgregor(1960) and Burns \& Stalker (1961) and began to flourish soon. In Hungary this topic got interest in the 1980s, among others in the works of Máriás, Kovács, Balaton, Tari and Dobák(1981), Varga(1983, 1986), and Kapitány, Á. \& Kapitány, G. (1983). The economic transition in Hungary brought a new wave of publications in this discipline written byHofmeister \& Bauer (1995), Bakacsi \& Takács (1997), Heidrich (1998) andDerjanácz (2000).

Several directions can be identified within the research of organizational culture, as some of its representatives were concerned with the definition of the elements of organizational culture and the relationship between organizational and national culture (Deal \& Kennedy,1982, Branyiczki, 1989and Daft, 1992), while others worked on typologies of organizational culture according to different variables, creating significant cultural models, likeHofstede (1980), Handy (1986), Schein (1996) and Trompenaars \& Hampden-Turner (1980). Based on the works of the authors mentioned above this study uses the following definition of organizational culture:"Organizational culture is a solid system of values, beliefs, assumptions, behaviors, methods, norms and habits shared by the members ofan organization, acquired through a learning process and applied and interpreted in the same way"[11].

Thus, one of the main issues is that although individual behaviors differ due todiverse genetics and socialization,theyconform if we regard larger economic entities like organizations. This is based on organizational culture as a common way of thinking providing a behavioral framework for groups and individuals.

It is regarded as a fact that the economic transition radically changed the Hungarian society and economy, which was certainly sensed in the life of households as well as in the macroeconomic behavior of organizations and the state [1], [3]. This study does not question the changes caused by the transition, however, it examines empirically if there is an influence of the past stateownership in the organizational culture of Hungarian companies after two decades.

To answer this question, the following hypothesis is establishedin the study:There is a detectable cultural difference between companies with a stateownership in the past and other companies operating in Hungary that were foundedafter the transition including thesubsidiaries of multinational companies.

\section{METHODOLOGY OF DATA COLLECTION AND DATA PROCESSING}

The most appropriate method to examine the accuracyof the previously stated hypothesis was a questionnaire-based research for which the data collection was finished in 2006. The structure of the questionnairecorresponds to the main dimensions of the national and organizational cultural research [7] and to the features of the international GLOBE research in organizational culture [2], since besides general information the questions refer to the four main dimensions of organizational culture identified by Hofstede (Power Difference, Uncertainty Avoidance, Individualism - Collectivism and Masculinity - Femininity), furthermore survey inquires the present situation and a desired organizational situation as well. All of the questions were to be answered on a Likert-scale with ninelevelsand every oddlevelis describedto orient respondents. Belowis an example of the structure of questions in the survey:

Table 1. Example of the structure of questions in the survey At your company...

II.3. a. ...who are the main agents of market success according to the value system of the organization?

\begin{tabular}{|c|c|c|c|c|c|c|c|c|}
\hline $\begin{array}{c}\text { Only the } \\
\text { employees }\end{array}$ & & $\begin{array}{c}\text { Mainly the } \\
\text { employees }\end{array}$ & & $\begin{array}{c}\text { Managers and } \\
\text { employees } \\
\text { equally }\end{array}$ & & $\begin{array}{c}\text { Mainly the } \\
\text { managers }\end{array}$ & $\begin{array}{c}\text { Only the } \\
\text { managers }\end{array}$ \\
\hline 1. & 2. & 3. & 4. & 5. & 6. & 7. & 8. & 9. \\
\hline
\end{tabular}

b. What would the desired value system be according to youregarding this?

\begin{tabular}{|c|c|c|c|c|c|c|c|c|}
\hline 1. & 2. & 3. & 4. & 5. & 6. & 7. & 8. & 9. \\
\hline
\end{tabular}

The survey does not qualify as representative, as the respondents were the first and second year students of the part time MSc course at the Faculty of Business and Economics, University of Pécs (who took part voluntarily and anonymously), thus the acquired sample does not represent entirely the features of Hungarian employees (sex, age, education, etc.) and their distribution just partly reflects the ratio of companies with past stateownership. Besides, based on the size of the sample the survey qualifies as a small group survey, since the database incorporates the answers of 115 students.

Although the deficiencies of representation and the small sample size limit the generalization possibilities of the survey results, it enables drawing basic conclusions, the justification of which is to be the subject of a more extensive empirical research. 
The processing of the collected data was done with SPSS (Statistical Package for the Social Sciences, Version 14.0) statistical analytical software. Besides giving codes to the answers, the variables had to be defined and named, which resulted in 44 variables ( 4 general questions and 10 questions in each of the four main topics).

The main aim of the data analysis was mapping the significant correlation between variables. This was done generating 946 cross tables using the 44 variables (see Table 2) from which the variable pairs with a significant explanation capability were filtered and Pearson's chi-squared test was used for the testing of significant correlations. Null hypothesis refers to a position that there is no relationship between two variables. If the results are significantly different from the null hypothesis, significant correlation can be justified between variables. This requires the fulfillment of the three conditions below.

1. The P-value representing the general significance level has to be lower than 0.05 , significance level of $5 \%($ the correspondence is indicated by $\mathrm{OK}$, while stronger correlations with $1 \%$ significance level is marked by $\mathrm{OK}^{*}$ and $0.1 \%$ level by $\left.\mathrm{OK}^{\star \star}\right)$.

2. The minimum expected value of the cells generated by cross tables (Min. E.F.)has to reach 1, meaning that all of the cells of the tableswere expected to have a value of no less than 1.

3. Less than $20 \%$ of the cells are allowed to have a value with an expected value of 5 , thus, the cells of cross tables has to be filled in on a determined level $($ CellsEF $<5)$.

The cross tables based on the original variables of the survey - because of the choices in the 9 level Likert-scale and the small sample size - did not indicate a correlation that satisfied the above criteria (mainly due to criteria 2 and 3 ). This meant that the variables had to be recoded. The answers were allocated into 3 groups that represented the cumulative frequency values of the first, second and third 3-element-set of the original 9 level scales. This transformation caused the completeness of cells with minimal modification of the information content of the original database. This resulted in 50 cross tables that fulfilled the 3 criteria. Table 2 below shows one of these cross tables.

Table 2. Example of the cross table of a significant correlation

(The cells include the observed counts and the expected values below them.)

\begin{tabular}{|c|c|c|c|c|}
\hline $\begin{array}{c}\text { VALLAL } \\
/ \\
\text { ERTRENDU }\end{array}$ & $\begin{array}{c}1 . \\
\text { Employees }\end{array}$ & $\begin{array}{c}2 . \\
\text { Both }\end{array}$ & $\begin{array}{c}3 . \\
\text { Management }\end{array}$ & $\begin{array}{c}\text { In Total } \\
\text { (\%) }\end{array}$ \\
\hline $\begin{array}{c}1 . \\
\begin{array}{c}\text { Former state-owned } \\
\text { companies }\end{array}\end{array}$ & $\begin{array}{c}1 \\
5.0\end{array}$ & $\begin{array}{c}14 \\
16.7\end{array}$ & $\begin{array}{c}22 \\
15.3\end{array}$ & $\begin{array}{c}37 \\
33.3 \%\end{array}$ \\
\hline $\begin{array}{c}2 . \\
\text { Companies with no } \\
\text { state ownership in the } \\
\text { past }\end{array}$ & $\begin{array}{c}14 \\
10.0\end{array}$ & $\begin{array}{c}36 \\
33.3\end{array}$ & $\begin{array}{c}24 \\
30.7\end{array}$ & $\begin{array}{c}74 \\
66.7 \%\end{array}$ \\
\hline $\begin{array}{c}\text { In Total } \\
(\%)\end{array}$ & $\begin{array}{c}15 \\
13,5 \%\end{array}$ & $\begin{array}{c}50 \\
45 \%\end{array}$ & $\begin{array}{c}46 \\
41,5 \%\end{array}$ & $\begin{array}{c}111 \\
100 \%\end{array}$ \\
\hline
\end{tabular}

The cross table above shows the relationship between the Past State Ownership of a company (VALLAL) and the Perceived Power Distancein attributing market success (ERTRENDU), which answers the question 'Who are the main agents of market success according to the values in your company?'. The cross table examines the distribution of companies with and without state ownership in the past and compares it with the expected frequencies. The conditions that determine the relation between the variables and their values are shown below:

Table 3. Criteria used to determine the relation between variables

\begin{tabular}{|c|c|c|c|c|c|c|c|c|}
\hline 1 & Var-2 & P-Value & Ev. & Min.E.F. & Ev. & CellsEF<5 & Ev. & $\begin{array}{c}\text { Final } \\
\text { Ev. }\end{array}$ \\
\hline VALLAL & ERTREN & 0.007490 & OK $^{*}$ & 5.000 & OK & $0.00 \%$ & OK & OK $^{*}$ \\
\hline
\end{tabular}

Thus, the correlation is good on a level of $1 \%$, there are no cells with an expected value of less than 5 and the minimum expected data-frequency in one cell is 5 (higher than the minimum of 1).After finding the significant correlations the next phase of the research consisted of the interpretation of cross tables and drawing a conclusion. 


\section{PROOFS OF CULTURAL DIFFERENCES}

From the aspect of the main hypothesis of the study the most important variable to research is the Past Ownership of a company (VALLAL): 'Was your company or its legal predecessor in state ownership before the transition?' Since the relations of this variable help to find out what cultural differences are between companies with and without past state ownership. Out of 115 respondents only 4 did not know about the past ownership of their companies, filtering these, 111 answers were processed when generating the cross tables. The distribution ofthe answers is shown below:

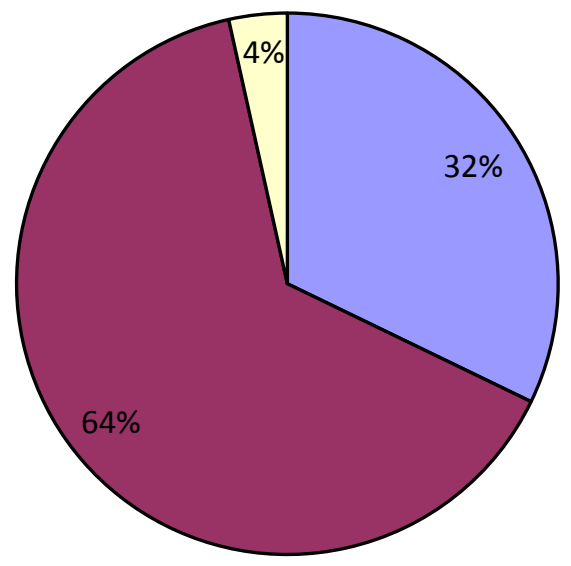

$\square$ Formerly state-owned companies (37)

$\square$ Companies with no state ownership in the past (74)

$\square$ Respondent does not know (4)

Figure 1: Distribution of respondents' companies based on past state ownership

The relevant relationships of the VALLAL variable were filtered out of the pairs with significant relation, which resulted in 9 significant relations, the most of all variables.In addition 2 further relations of the VALLAL variable were found with a partial justification power based on the cross tables of the VALLAL variable.

After the analysis of the 11 tables, the following can be stated about the differences in the organizational culture of companies with or without past state ownership:

\subsection{Previous State Ownership vs. Agents of Market Success According to Company Value System}

The correlation has a higher level of significance $\left(\mathrm{OK}^{\star}\right)$, which shows that in companies that were previously owned by the state,the leaders are regarded to be responsible for the success and the administering of top management directives, while in other companies employees are the key to success and the joint effort of the collective is more appreciated.

\subsection{Previous State Ownership vs. Desired Influenceof Rules Restricting Management Power}

This correlation also has a higher significance $\left(\mathrm{OK}^{\star}\right)$ and the cross table data show that both the managers and employees of companies with past state ownership intend to describe the power of management more thoroughly, whereas in other companies more freedom is desired for the managers in accomplishing their duties. A possible reason for this is that processes in a state-owned company were based on strict bureaucracy, while in other companies targets are accomplished with a flexible response to external factors. The significant relation between these variables also shows that companies with state ownership in their past have a large Power Distance, since the managershave a distinguished role, while other companies may have smaller Power Distance, since both the managers and employees trust the success of joint efforts.

\subsection{Previous State Ownership vs. the Acceptance of Employees'Innovative Ideas}

The relationship of these two variables show that companies with past state ownership rather inhibit the innovative ideas of employees, thus the main expectation towards them is to accomplish their prescribed task, whileother companies encourage the innovative ideas of employees. This relation reflects an old cultural feature of state-owned companies, that innovation is the sole responsibility of managers.

\subsection{Previous State Ownership vs. Work Rules}

The survey showed that companies with a past state ownership have an extensive regulation regarding work activity, while in other companies the main principle is that everyone should do their job efficiently. Work rules can also be an industry specific issue; however, the dominance of technocratic coordination and its consequences in organizationalbehavior is significant. 


\subsection{Previous State Ownership vs. Expected Level of Work Rules}

Related to the previously discussed variable, the connection between the extent of rules expected by employees and the VALLAL variable has a remarkably high significance level $\left(\mathrm{OK}^{\star}\right)$. The findings of the present survey support the assumption that employees of companies with past state ownership expect an even more detailed regulation of their job, while respondents in other companies wish to have more deliberated work rules. This indicates that theorganizationalcultural behavior of companies with different past ownership does not converge, but on the contrary, diverges.

The Uncertainty Avoidance is represented by two additional variables and even though they did not fulfill the three significance criteria, two observations can be made:

\section{Previous State Ownership vs. the Expected Stress Level at the Workplace}

The relation between the two variables is sufficient (OK), but does not fulfill the second and third significance criteria, thus due to the small sample the completeness of the cells in the cross tables is low, which causes a lower explaining potential of the results. It was found that employees of formerly state-owned companies wish to have morevariety at work, while in other companies, employees long for a more relaxed atmosphere. At formerly state-owned companies the respondents gave a contradictory reply because they wished both more detailed rules in their jobs (that can lead to monotony) and a more changing, however more stressful work.

\section{Previous State Ownership vs. Desired Risk Taking}

The connection of these two variables fails to fulfillonly the third criterion that is because of the small sample size. Employees of companies with a past state ownership would welcome the possibility of higher risk taking, while in other companies such behavior is desired even to be the basis of their career.

The research shows that Uncertainty Avoidance is the area with the greatest difference between companies with and without state ownership in their past, since it is supported by three significant and two partially significant correlations. The findingsshow that the organizational culture of companies with a state past is considerably more uncertainty avoiding (despite of their desire for more change accompanied by stress) than that of others.

\subsection{Previous State Ownership vs.the Frequency of Working in Groups}

The significant correlation of these variables shows that - within the Individualism vs. Collectivism dimension - tasks are rather completed individually in companies with past state ownership (depending on the type of the problem), while in other companies groupwork is the dominant form of problem solving.

\subsection{Previous State Ownership and the Main EmployeeGoals}

Fulfilling the criterion of the higher significance level $\left(\mathrm{OK}^{\star}\right)$ the relation of the variables shows that the main goal of employees at companies with past state ownership focuses on building connections, whereas in others besides individual career goals the belonging to an organizational group is the most important. It can be argued that at formerly state-owned companiesthe individual relational capital maximizing aims of the past era left their marks, as a career was managed through background agreements between individuals without any role of the organizational group.

Examining the Collectivism vs. Individualism dimension in organizational culture, the present survey shows that the culture of former state-owned companies is more individualist, while that of others have more collectivist features.

\subsection{Previous State Ownership and the Empathy of Managers for Employees inConducting Performance Evaluation}

While the managers in companies with past state ownership are dominantly performance-oriented according to the respondents, in other companies besides focusing on performance targets managers have more empathy for employees. As a possible explanation, the pressure of meeting the requirements of central plans in the socialist era still results in less consideration for human and qualitative factors by managers.

\subsection{Previous State Ownership and the Expected Empathy of Managers for Employees inConducting Performance Evaluation}

According to the research all employees expect their managers to be more empathic; however, in former state-owned companies this expectation is moderate, while in others it is very strong.

Regardingthe Masculine vs.Feminine cultural dimension, the survey showed that companies with previous state ownership have cultural characteristics that are closer to masculine values (even though their employees wish for empathy), while those of other companies are rather feminine. 


\section{A FURTHER INTERESTING RELATION: THE INTERNAL INFORMATION FLOW AS A MAIN CULTURAL FEATURE}

The significant relation pairs in the cross tables showed that besides the variable VÁLLAL, another variable, namely the information flow between managers and employees (INFOÁRUJ), has an important role (8 correlations). Although the past state ownership of companies and the freedom in their information flow does not show a correlation in the sample, it has to be highlighted that information flow is one of the main characteristics of organizational culture. We made the following observations regarding this:

1. Organizations with a free flow of information boost innovation, whereas in organizations with a minimal flow of information the innovation initiated by employees is rather disapproved of. In the given sample this statement is firmly proved, since it has a very high significance level $\left(\mathrm{OK}^{* *}\right)$. Its explanation may be that if managers do not share information with employees on lower hierarchy levels, they feel they do not need their advice and ideas to handle the current situation in the organization.

2. Organizations with a free information flow are generally more relaxed workplaces, while the employees of others live with constant tension, probably because of the insecurity caused by the lack of information.

3. Organizations with a free flow of information plan in a longer time scale (several years), while the decision makers of others plan only in shortterm. The latter may be caused by the low level of shared information. This correlation had a very high significance level $\left(\mathrm{OK}^{*}\right)$.

4. In organizations with a free flow of information managers tend to have a relationship oriented and empathetic leadership style, while those of other organizationshave performance oriented leadership style. At the former organizations the free communication flow enables employees to know about each other's' problems and situation, whereas in the latter organizations employees are only evaluated based on their completed work. This explains the high significance level $\left(\mathrm{OK}^{* *}\right)$ shown by the analysis.

5. In organizations with a free flow of information employees regard the social sensitivity of managers important, while in others organizations this is considered to be disadvantageous. The connection between these two variables is similar to that of the variable pair in Point 4 , it is within the $0.1 \%$ significance level $\left(\mathrm{OK}^{\star \star}\right)$. Theserelationsare related to the Masculine vs. Feminine categories of the Hofstede model. This seems to be logical, since only those managers can lead with a human focus, who know their employees, while in an environment with limitedcommunication flow it is regarded as an irresponsible indulgence even by the employees.

6. Organizations with a free flow of information aim to handle conflicts primarily through negotiation and consensus, while others trust mainly managerial directives.

Based on the former three variable pairs of the given sample, a more general assumption can also be made, according to which the free flow of information is a characteristic of feminine organizations, while a limited communication flow strengthens the masculine qualities in organizations.

\section{CONCLUSION}

Organizational culture, as a qualitative element of organizationalbehavior, is certainly a complex organizational feature that is difficult to measure,however, the method of testing a hypothesis enables researchers to conduct a comparative analysis as means of measuring its characteristics. The subject of this analysis was the hypothesis that the organizational behavior of companies with a past state ownership differs from that of other companies.

In my opinion, the results of the conducted research reinforced the assumption that the political and economic conditions before the transition left remainders in individuals, groups and companies, which are stilltraceable in today's organizational culture in Hungary. Since this effect can be proven two decades after the transitionin Hungary, the present study can be a useful addition to the analysis of the dynamics of organizational culture changes. Naturally the results of this research should be refined by further research. It was also the author's aim to direct the attention of other researchers towards the actuality of this topic.

\section{REFERENCES}

[1] Antal-Mokos, Z. and Kovács, P., "Magyar vállalati stratégiák az 1990-es évek első felében - taxonómia", Vezetéstudomány, 2 (1998)

[2] Bakacsi, Gy. and Takács, S., "Honnan - Hová? A nemzeti és szervezeti kultúra változásai a kilencvenes évek közepének Magyarországán", Vezetéstudomány 2 (1998), 15-22.

[3] Balaton, K., "Vállalati stratégiai magatartás az átmenet időszakában (1990 - 1994)", Vezetéstudomány, 9 (1994)

[4] Branyiczki, I., "Szervezeti kultúrák empirikus vizsgálata", Közgazdasági Szemle 18 (1989), 94-106.

[5] GLOBE projekt: A vezetés és a szervezeti magatartás hatékonyságának nemzetközi vizsgálata, Kutatási kérdőív

[6] Hofstede, G. 1980. Culture's Consequences: International Differences in Work Related Values., Beverly Hills, CA: Sage Publications

[7] Hofstede, G., "National cultures in four dimensions", International Studies of Management and Organization, 13/2 (1983), $46-74$. 


\section{ISSN 2321-1091}

[8] Hofstede, G., Neuijen, B., Ohavy, D. D. and Sanders, G., "Measuring Organizational Cultures", Administrative Science Quaterly, Vol. 35, 1990, 286 - 316.

[9] Jarjabka, Á. 2001, "A kultúra hatása a szervezetek stratégiájára", Vezetéstudomány, 3 (2001), 16 - 26.

[10] Jarjabka, Á. 2003., "A magyar nemzeti - szervezeti kultúra pozíciója a hofstedei modellben", Marketing \& Menedzsment, 1 (2003) 29-45.

[11 Jarjabka, Á. 2004., "Szervezeti kultúrakutatás és az Ember Erőforrás Menedzsment - vizsgálatok a magyar szervezeti kultúra témakörében", Személyügyi Hírlevél, 2004. szeptember, 31 - 39.

[12] Lau, C.-M. and Ngo, H.-Y. 1996., "One Country Many Cultures: Organizational Cultures of Firms of Different Country Origins", International Business Review, Vol.5., No.5. 1996, 469 - 486.

[13] Pearce, J. L. 1991., "From socialism to capitalism. The effects of Hungarian human resources practices", The Academy of Management Executive, 5/4 (1991), 63 - 74.

[14] Trice, H. M. and Beyer, J. M. 1993. The Cultures of Work Organizations, Englewood Cliff, NJ: Prentice Hall

[15] Trompenaars, F. and Hampden-Turner, C. 1998. Riding The Waves of Culture, Understanding Cultural Diversity in Business, London: Nicholas Brealey Publ.

\section{Author' biography with Photo}

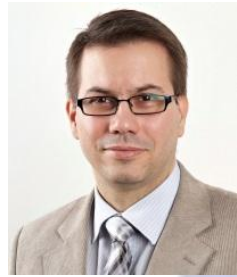

Ákos Jarjabka, PhD is an economist with a complementary degree in Law, Associate Professor and Associate Dean of Academic and General Affairs of the Faculty of Business and Economics, University of Pécs, Hungary. He is Director of the Centre for Further Studies and Fundraising and Head of the Management Department. His main research areas are Cross Cultural Management, Human Resource Management and Project Management. 